\title{
Chemical control of Aedes aegypti: a review on effects on the environment and human health
}

\author{
Controle químico do Aedes aegypti: revisão dos efeitos ao meio ambiente e saúde humana \\ Stefany Rodrigues de Oliveira ${ }^{1}$, Ronaldo Roberto Tait Caleffe ${ }^{2}$ e Helio Conte ${ }^{3}$ \\ ${ }^{1}$ Biotecnóloga e Mestranda em Biotecnologia Ambiental, Departamento de Biotecnologia, Genética e Biologia Celular - UEM, \\ Maringá-PR-Brasil \\ ${ }^{2}$ Biotecnólogo e Mestrando em Biotecnologia Ambiental, Departamento de Biotecnologia, Genética e Biologia Celular - UEM, \\ Maringá-PR-Brasil \\ ${ }^{3}$ Professor, Doutor, Departamento de Biotecnologia, Genética e Biologia Celular - UEM, Maringá-PR-Brasil \\ s.r.oliveira@outlook.com; ronaldo_caleffe@hotmail.com; helconte@gmail.com
}

\begin{abstract}
Aedes mosquitoes are known to be infected by arboviruses causing disease such as dengue, zika fever, and chikunguya fever, and subsequently transmit them, to humans through the bite of infected females. Chemical control is a measure adopted as part of sustainable management and integrated vector control for public health. There are four principal classes of insecticides used for controlling mosquitoes, all being neurotoxic: organochlorides, organophosphates, carbamates, and pyrethroids. The objective of this work was to review reports on the environmental effects of the insecticides most commonly used for controlling Ae. aegypti. This bibliographic study was conducted using articles and books available in the literature with no time restriction. The databases accessed were: Google Scholar, Pubmed, SciELO, and ScienceDirect. These insecticides exhibit toxicity to the environment, and may accumulate in food and water and in the body of vertebrates. Resistance to different insecticides is a problem when the mode of control is chemical, because insects survive insecticide application and higher doses are necessary for controlling the vectors. Considering these results, the ideal method would be the newly proposed means of mosquitoes control using technology related to modern biotechnology.
\end{abstract}

Keywords: Mosquitoes; Insecticides; Environmental; Toxicity

\section{Resumo}

O gênero Aedes é reconhecido por ser infectado por arbovírus, e transmiti-lo, causando dengue, zyca vírus e febre Chikungunya, para humanos devido a picada da fêmea infectada. Controle químico é umas das medidas mais adotadas como parte do manejo sustentável e integrado no controle de vetores para Saúde Pública. Existem quatro principais classes de inseticidas utilizados para o controle do mosquito, todos neurotóxicos: Organoclorados, organofosforados, carbamatos e piretróides. O objetivo deste trabalho foi apresentar os efeitos ambientais descritos pelos inseticidas mais utilizados no controle do Ae. aegypti. A revisão bibliográfica foi baseada em artigos e livros publicados na literatura cientifica sem limitação de tempo. Os bancos de dados utilizados foram: Google Scholar, Pubmed, SciELO and ScienceDirect. Os inseticidas apresentam toxicidade ao meio ambiente, acumulam em alimentos, aguas e no corpo de vertebrados. Resistência a diferentes inseticidas também é problemático quando a estratégia é o controle químico, pois a sobrevivência do inseto gera doses maiores de inseticidas para o controle do vetor. Considerando estes resultados, o ideal seria a proposta de novos controles do mosquito utilizando tecnologias relacionadas a biotecnologia moderna. 


\section{INTRODUCTION}

The family Culicidae, of the order Diptera, is of great importance to public health, owing to the genera Culex (Linnaeus 1785) and Aedes (Meigen 1818). Aedes mosquitoes are known for being infected by arboviruses, and subsequently, transmitting these viruses to humans through the bite of infected females (CONSOLI and OLIVEIRA, 1994). Arboviruses of the Flaviviridae family, transmitted by mosquitoes, can cause diseases such as dengue (DENV, with four serotypes, DEN-1, DEN-2, DEN-3, and DEN-4) and dengue hemorrhagic, zika fever (ZIKV), responsible for the large increase in the number of microcephaly cases in Brazil (MURPHY and LONG, 2016), and chikungunya fever (CHIKV, an Alphavirus) (PIALOUX et al, 2007).

Aedes aegypti is the main vector of the above mentioned diseases, although not the only one. It is a domestic species with a preference for human blood. Adults feed on carbohydrates, and females require blood for reproduction; therefore, if the mosquito is infected with a virus, it will be transmitted to the host upon biting, owing to the presence of the virus in the mosquito saliva. Virus transmission can occur vertically, when an infected female transmits the virus to part of its progeny, or when an adult bites an infected host, such as humans (CONSOLI and OLIVEIRA, 1994).

Chemical control with organic or inorganic insecticides is one of the most widely adopted methods as part of sustainable and integrated management for vector control in public health (ROSE, 2001).

Insect control practices are extremely old. There is a record of such practices in China for over 2,000 years. They were biological control practices aimed at handling agricultural pests. In the late nineteenth century, certain species of insects and other arthropods were discovered to be responsible for transmitting some of the most important diseases. (BRAGA et al, 2007).

There are four main classes of insecticides used, all of which are neurotoxic: organochlorides, organophosphates, carbamates, and pyrethroids. Organochlorides are chemicals containing carbon, hydrogen, and chlorine. They are classified into four groups, according to their chemical compounds: diphenyl aliphatic, hexachlorocyclohexane, cyclodienes, and polychloroprenes (WARE, 2000). The generic term "organophosphates" encompasses all insecticides containing phosphorus. These insecticides were discovered subsequent to organochlorides (CRIONNION, 2000). Organophosphate insecticides are classified into three groups: aliphatic compounds (Malathion, Dichlorvos, Dicrotopho, and so on), phenyl derivatives (ethyl- and methyl parathion, fenitrothion, etc.), and heterocyclic compounds (chlorpyrifos, chlorpyrifos-methyl, and so on). Carbamates are chemicals derived from carbamic acid, and their commercialization began in the 1960s. A widely used carbamate is carbaryl. Similar to organophosphates, carbamates have rapid lethal action against insects, despite low residual activity (WARE, 2000). Synthetic pyrethroids, which are currently quite stable, are produced in the laboratory from a natural substance called pyrethrins extracted from chrysanthemums. Pyrethroids have the advantage of being highly active in small doses in action against mosquitoes. This insecticide react with sodium channels on nerves, prolonging the time that channels are open, resulting in an altered function of nerves. (PALCHICK, 1996)

Considering the harmful effects of insecticides on human health and the environment, the objective of this work was to present reports on the environmental effects of the insecticides most commonly used for controlling Ae. aegypti.

This bibliographic study was conducted based on articles and books available in the literature with no time restriction. The databases accessed were Google Scholar, Pubmed, SciELO, and ScienceDirect, using the words organochlorides, organophosphates, carbamates, pyrethroids, Aedes aegypti, human health, and environmental. The selection of articles for preparing the review included papers published in Portuguese, Spanish, and English available in full-text versions with relevance to the discussed topic.

\section{RESULTS}

Since the 1990s, until 2017, several research papers have been published on the effects of insecticides on human health and environment. The analysis of the aims of the paper read revealed a similarity in the research studies; and, in this review, we summarize the principal effects of insecticides. Twenty nine research papers published between 1994 and 2017 were selected for preparing 
this systematic review. The papers were selected according with the review theme, toxicity to human health and environment.

\section{AEDES AEGYPTI}

The adults, popularly known as mosquitoes, present in their morphology the posterior border of the trilobate scutellum and the short palps for the females, the eggs are devoid of floats, larvae spiracles are implanted at the end of a siphon ranging from short to very long (CONSOLI and OLIVEIRA, 1994). Aedes are nocturnal or crepuscular afternoon species with aggressive and opportunistic characteristics, perform a single oviposition on the liquid surface or on a humid substrate, near the water or in a local flood. A laying of eggs is performed above water level and their breeding grounds can be artificial, such as flower pots, tires, cans or any container that contains water, or natural such as, bamboos, bromeliads, fallen leaves, etc. Due to the need of water for development, the population of these insects varies during the year, increasing the density in the presence of rains and high temperatures and reducing the dry season and lower temperatures (LOPES et al, 2014). In this way the eggs of these mosquitoes are resistant to desiccation, remaining viable within a period of more than a year, and hatching with contact with water (CONSOLI and OLIVEIRA, 1994).

The transience of breeding grounds, conditioned by the presence of water, necessitates rapid development of the larval and pupal stages, because the need for the cycle to be complete prior to evaporation of the water-containing vessel (CONSOLI and OLIVEIRA, 1994). The development cycle of Ae.aegypti is holometabolous, involving egg phases (resistant up to 450 days), four larval stages (from seven to nine days) and pupa (two to three days), being the temperature a relevant factor in its development, that is, at high temperatures the life cycle of the mosquito is faster (CASTRO et al., 2013; LOPES et al, 2014) and the females lay the eggs in batches of 50 to 500 eggs (CONSOLI and OLIVEIRA, 1994). Ae. Aegypti was originally described in Egypt, being now cosmopolitan, present in tropical and subtropical regions (BHATT et al, 2013). In the 50s this mosquito was eradicated from the Brazilian territory, due to the fight against yellow fever, however neighboring countries did not eradicate it allowing its reintroduction in the decade of 60 (CONSOLI and OLIVEIRA, 1994).

\section{INSECTICIDES}

Chemical control using organic or inorganic insecticides is one of the most commonly adopted methods as part of sustainable management and integrated vector control for public health (ROSE, 2001). There are four main classes of insecticides used, all of which are neurotoxic for insects: organochlorides, organophosphates, carbamates, and pyrethroids (Table 1). Furthermore the indiscriminate use of insecticides cause damages not only to insects, additionally to human health and to the environment.

Table 1 - Insecticide groups and their effects on insects.

\begin{tabular}{c|c|c|c}
\hline Chemical group & Insecticides & Effects on insects & Year of introduction \\
\hline Organochlorides & $\begin{array}{c}\text { DDT } \\
\text { (Dichlorodiphenyltrichloethane }\end{array}$ & $\begin{array}{c}\text { Hyperexcitation } \\
\text { of neurons }\end{array}$ & 1940 \\
\hline Organophosphates & Temephos, Malathion, Pirimiphos- \\
methyl & $\begin{array}{c}\text { Inhibition of } \\
\text { cholinesterase, } \\
\text { Elevation of } \\
\text { acetylcholine level }\end{array}$ & $\begin{array}{c}\text { Carbaril, Bendiocarb } \\
\text { Carbamates }\end{array}$ & $\begin{array}{c}\text { Accumulation } \\
\text { of acetylcholine, } \\
\text { carbamylation } \\
\text { Paralysis } \\
\text { involving the } \\
\text { central and } \\
\text { peripheral } \\
\text { nervous systems }\end{array}$ \\
\hline Pyrethroids & Deltamethrin & 1960 \\
\hline
\end{tabular}


Organochlorides

The diphenyl-aliphatic organochloride group is the oldest group of insecticides used against insect pests. They include DDT, which is probably the most notorious chemical used in the last century. Its effect is inversely proportional to temperature - the lower the temperature, the more toxic DDT is to insects (WARE, 2000).

The insecticides of this group affect sodium channels in insects, and therefore, these channels remain open for longer, resulting in the continuous transmission of nerve impulses. Therefore, the death of the insects should hyperexcitation. Organochlorides are soluble in lipids, and therefore accumulate in fat bodies, affecting the entire food chain, at the top of which humans are ranked. The presence of these compounds in the ocean causes serious environmental problems, such as biomagnifications in dolphins and reduced reproduction of sea trout. These compounds decrease the fertility of birds, because of changes in calcium metabolism and inhibition of carbonic anhydrase, which is important for egg formation. (FLORES et al, 2004)

In humans, effects are observed on the central nervous system and immune system. Chlorides pesticides can be introduced on organism thorough the cutaneous, digestive and respiratory via, causing serious liver and kidney damages, additionally to brain, DNA, heart and bone marrow (FLORES et al, 2004). Exposure to pesticides by contact can be related to human cancer. Animal studies have proven that the disruption of the endocrine system by these insecticides can lead to cancer, since cancers of the breast, ovary, prostate gland, testes, and thyroid are hormone-dependent. (EJAZ et al, 2004) Exposure through diet is another mode of contamination. Fatty foods are major causes, since these insecticides are fat-soluble, and persist in the environmental, leading a several research relating damage of this chemical to human health (JAYARAJ et al, 2016).

Rivero et al, 2016 evaluated the potential effects of organochlorides in breast cells. The results confirmed that the insecticide exerted effects on gene expression, up-regulated the expression of oncogenes associated to breast cancer (GFRA1 and BHLHB8) and down-regulated tumor suppressor genes (EPHA4 and EPHB2). The results indicate that altered gene expression can lead the development of cancer in these cells, whereas the mechanism of cancer involve up-regulation of oncogenes and down-regulation of suppressor genes.

This group of insecticides cause decline in the populations of raptorial birds, such as the peregrine falcon, sparrowhawk, and bald eagle through the inhibition of the GABA (gamma-Aminobutyric Acid) receptor in the brain. Furthermore, in sublethal doses, organochlorides can disrupt the endocrine system and affect the feeding behavior and immune system, resulting in reduced reproduction and declining population of birds (MITRA et al, 2011). Sarah et al (2011) studied different organochlorides in tissues of the Greater cane rat (Thryonomys swinderianus), and observing that Aldrin and heptachlor were the principal contaminants in the muscles, liver, and kidney.

Since the damages cause by this class of insecticide has been proved to humans and environmental in several studies, the use of it in management programs of vector control has not been used. Organophosphates

They are widely used, because they have many advantages over organochlorides, such as biodegradability and absence of accumulation in tissues. However, the main drawback of their use is chemical instability, makes periodic application mandatory (PALCHICK, 1996; WARE, 2000). This class causes the large accumulation of acetylcholine (ACh) in nerve endings, which is an important neurotransmitter that, under normal conditions, is degraded by cholinesterase (ChE), and in insects, cholinesterase inhibition by organophosphates increases the accumulation of acetylcholine.

Furthermore, they are more toxic to vertebrates than organochlorides, even at relatively low doses (BECKER et al, 2003). Because of low resistance, organophosphates can be used as alternatives to the persistent organochlorides, especially DDT. In humans, all pathways can circulate these insecticides, which reach the adipose tissue, liver, kidneys, salivary glands, thyroid, pancreas, lungs, stomach, intestine, central nervous system, and muscles. However, since they do not accumulate in tissues, organophosphates can be biotransformed in the liver. In the environment, the degradation of organophosphates varies from 1 to 12 weeks with the possibility of retention in by-products or waste at levels harmful to health, as shown in a study conducted in Rondinha - Rio Grande do Sul, where 5 of 15 collection points exhibited detectable contamination (GRIZA et al, 2008).

Nganchamung et al (2017) evaluated blood samples from 90 chili farmers exposed to pesticides 
(for erythrocyte acetylcholinesterase (AChE) and plasma cholinesterase (PchE)). The results showed that in half of the farmers, both enzymes were abnormal, showing that exposure to insecticides causes damage to human health. A case control studied 357 incident Parkison Diseases (PD) and 752 population control in Central Valley of California, to evaluate the increase risk of developing PD cause by different organophosphates. The data show evidence that exposure to OP increase the risk of PD (WANG et al, 2014).

Carbamates

These are chemicals derived from carbamic acid, and their commercialization began in the 1960s. One of the most widely used carbamate is carbaryl. Similar to organophosphates, carbamates have rapid lethal action against insects, despite low residual activity. Concerning plants, they are systemic insecticides, because they are relatively soluble in water. Additionally, organophosphates cause acetylcholine accumulation, although the reaction involved is carboxylation (WARE, 2000). Its use is effective in controlling organisms resistant to organochlorides and organophosphates; carbamates inhibit the activity of acetylcholinesterase (AChE), which is an enzyme catalyzing the hydrolysis of acetylcholine. Carbamates are potentially toxic to humans; they may exert adverse effects on the central and peripheral nervous systems, and be immune-suppressing or carcinogenic, among others. Carbamates do not accumulate in the body; however, their effects are cumulative (ESCAMEZ et al, 2006; MINISTRY OF HEALTH, 1998).

When applied improperly to the field, these substances can contaminate waterways, in addition to generating residues in agricultural products. Animals consuming water or food contaminated with these substances accumulate them in fat and muscles, and these carbamates could be present in milk (ROTHWEEL, 2001).

Carbamates act on human immune system by oxidative stress, inhibition of cholinesterase and endocrine disruption. The stress oxidative induce damages on DNA, lead mutations on cells of immune system, increasing risks of infection and cancer. This insecticide can alter lymphocytic cholinergic signaling through the inhibition of acetylcholinesterase triggering inflammatory response increasing infection, inflammations and cancer. Additionally carbamates cause a disrupt on endocrine system through deregulation on gonadotropin hormone in hypothalamus gland, leading an alteration in cortisol secretion (adrenal gland) change cytokine network, increasing risks of cancer, allergy, autoimmunity and infection (DHOUIB et al, 2016).

Pyrethroids

They are biodegradable, do not accumulate, and rarely cause acute poisoning in birds and mammals, although they can cause the sensitization and irritation of the mucous membranes of these animals. However, they are extremely toxic to aquatic animals. The lethality of pyrethroids involves the peripheral and central nervous systems (HEMINGWAY et al, 2004).

The low availability of data on pyrethroid residues in food is due to the noninclusion of its analysis in monitoring programs conducted by different institutions. The presence of pesticide residues at levels exceeding permitted limits or in unauthorized crops may cause public health and ecological problems, and serve as a commercial barrier as well, in both the domestic and external markets. Teixeira et al (2003) conducted a prevalence study on 98 workers with a mean age of 41.6 years exposed to organophosphate pesticides and pyrethroids used in vector-control campaigns. The workers were divided into 2 groups. Group 1 did not report exposure to noise in current and past work and/or leisure time, and group 2 reported exposure to noise in current or previous work and/or leisure time. The most frequent complaints were eye irritation (54.1\%), headache (44.9\%), dizziness $(35.7 \%)$, nausea, and torpor $(16.3 \%)$. The most commonly reported symptoms related to the central nervous system were difficulties in understanding what was said (46\%), difficulty in remembering certain facts (43\%), difficulty in maintaining attention (24\%), and hearing (24\%). Of those exposed only to insecticides, $63.8 \%$ had hearing loss and for the group exposed to insecticides and noise, hearing loss was $66.7 \%$. The authors concluded that there was evidence proving that exposure to pesticides induces peripheral auditory damage, and noise is a factor that interacts with pesticides, and enhances their cytotoxic effects.

A correlation of exposure of pyrethroids and men infertility was carried out on research by Jurewicz et al, 2015. 286 men under 45 years with normal sperm concentration were interviewed and provided urine, saliva and sêmen samples. The metabolites of insecticide were analyzed and a positive association was observed between insecticide exposure and DNA fragmentation. The results suggests 
that pyrethroids and DNA damage on sperms are correlated, enhance the concern about indiscriminante use of pesticides.

\section{Resistance of AEDES AEgyPti}

The use of insecticides for insect control poses the problem of resistance development. Because of the population pressure created in Ae. aegypti owing to chemical control, this mosquito is resistant to certain insecticides, such as the organophosphate, temephos and the pyrethroid, deltamethrin (BELLINATO et al, 2016).

Reduced penetration of insecticides, mutations on target-proteins and enhanced enzymatic biodegradation or sequestration are the mechanisms recognized to provide resistance to mosquitoes. Target-proteins mutation and metabolic resistance (increase in enzymatic activity of esterases, oxidases, and Glutathione S-transferase) are the main mechanisms of resistance in Aedes, and reduce penetration, cause by modifications on cuticle, remains poorly understood being necessary confirmation (MOYES et al, 2017).

In Latin America, several Ae. Aegypti populations have developed high resistance to organophosphates, carbamates, and pyrethroids, and high activities of detoxifying enzymes are responsible for this observation. Mutations in the genes encoding transmembrane sodium channels have been suggested to confer resistance to pyrethroids and DDT (MANJARRES-SUAREZ and OLIVERO-VERBEL, 2013).

The organophosphate temephos has been used in Brazil, since the past century, against Ae. aegypti, and replaced by pyrethroids in beginning of past decade. A research group, responsible for detection of insecticide resistance (Brazilian Health Foundation: Insecticide Resistance Monitoring Program), evaluated the mosquitoes of 12 multiplicities of Rio de Janeiro, Alagoas and Sergipe during 2001. All larvae group utilized in this research were resistance to temephos, indicating that vector control with temephos are not effective against Ae. aegypti (BRAGA et al, 2004).

A study developed in Madeira Island (Potugal) utilized three classes of insecticides against Ae. aegypti: Carbamates (Bendiocarb), Organophosphates (Fenitrothion) and Pyrethroids (Permethrin and Cyfluthrin), demonstrated resistance to all, excepted to a case of Fenitrothion in Paúl do Mar. In this work were utilized bioassays of susceptibility and biochemical and microarray RNA in order to confirm the mechanisms of resistance. The author concluded that resistance was linked with multiple mechanisms, include tarket-side ( $\mathrm{kdr})$, metabolic resistance and cuticle thickening. The results indicated that a reverse of resistance is challenging, whereas the resistance is multifactorial (SEIXAS et al, 2017).

\section{CONCLUSION}

Insects transmitting viruses such as DENV, ZIKV, and CHIKV, are controlled using various insecticides, each with a specific mechanism of action. However, these insecticides exhibit toxicity to the environment, and may accumulate in food and water and in the body of vertebrates. Resistance to different insecticides is a problem, when the mode of control is chemical, because insects survive insecticide application and higher doses are necessary for controlling vectors. Additionally, the data provided by the Ministry of Health and generated in several studies indicate damage to humans and the environment; however, they do not indicate effectiveness in controlling insects. The results shown in the epidemiological bulletin of Brazil revealed 1.500.535 dengue cases, 271.824 chikungunya, and 215.319 zika fever cases in 2016. Considering these results, the ideal method would be the newly proposed means of virus control using technology related to modern biotechnology and vaccine development, as well as public awareness of the need to prevent mosquito breeding.

\section{ACKNOWLEDGMENT}

The authors would like to thank the Araucaria foundation and CAPES for financial support. 


\section{REFERENCES}

Becker N, Zgomba M, Petric D, Dahl C, Boase C, Lane J, et al. Mosquitoes and their control. 1. ed. New York: Kluwer Academic/Plenum Publisher; 2003.p.498.

Bellinato DF, Viana-Medeiros PF, Araújo SC, Martins A, Lima JBP, et al. Resistance Status to the Insecticides Temephos, Deltamethrin, and Diflubenzuron in Brazilian Aedes aegypti Populations. BioMed Research International. 2016;1-12.

Bhatt S, Gething PW, Brady OJ, Messina JP, Farlow AW, Moyes CL, et al. The global distribution and burden of dengue. Nature. 2013;496(7446):504-507.

Braga AI, Valle D. Aedes aegypti: inseticidas, mecanismos de ação e resistência. Epidemiol. Serv. Saúde. 2007;16(4):279-273.

Castro FP, Martins WFS, Filho MLL, Almeida RP, Beserra EB. Ciclos de vida comparados de Aedes aegypti (Diptera, Culicidae) do semiárido da Paraíba. Iheringia. 2013;103(2):118-123.

Consoli RAGB, Oliveira RL. Principais mosquitos de importância sanitária no Brasil. 1.ed. Rio de Janeiro: Editora FIOCRUZ, 1994.p.228.

Crinnion WJ. Environmental Medicine, Part 4: Pesticides - Biologically Persistent and Ubiquitous Toxins. Alternative Medicine Review. 2000;5(5):432-447.

Dhouib I, Annabi A, Jallouli M, Marzouki S, Gharbi N, Elfazaa S, et al. Carbamates pesticides induced immunotoxicity and carcinogenicity in human: A review. J. Appl. Biomed. 2015;14(2):85-90.

Ejaz S, Akram W, Lim CW, Lee JJ, Hussain I. Endocrine disrupting pesticides: a leading cause of cancer among rural people in Pakistan. Exp. Oncol. 2004; 26(2):98-105.

Escámez JC, Rubí JCM, Rodríguez FY. Intoxicación por Organoclorados, Carbamatos y Herbicidas. In: Cebrián JG, Rosety RDA, Coma MJ, Bello DG. Principios de Urgencias, Emergencias y Cuidados Críticos. 2006. Available from: http://tratado.uninet.edu/indice.html.

Flores AV, Ribeiro JN, Neves AA, Queiroz ELR. Organoclorados: um problema de saúde pública. Ambiente \& Sociedade. 2004;2(2).

Fundação Nacional da Saúde, Ministério da Saúde. Intoxicações por agrotóxicos. Brasília (Brasil): Ministério da Saúde. Guia de Vigilância Epidemiológica, 1998.1-17 p.

Griza FT, Ortiz KS, Geremias D, Thiesen FY. Avaliação da contaminação por organofosforados em águas superficiais no município de Rondinha - Rio Grande do Sul. Quim. Nova. 2008;31(7):1631-1635.

Hemingway J, Hawkes NJ, Mccarroll L, Ranson H. The molecular basis of insecticide resistance in mosquitoes. Insect.Biochem. Mol. Biol. 2004;34(7):653-65.

Jayaraj R, Megha P, Sreedey P. Organochlorine pesticides, their toxic effects on living organisms and their fate in the environment. Interdiscip Toxicol. 2017;9(3-4):90-100.

Jurewicz J, Radwan M, Wielgomas B, Sobala W, Piskunowicz M, Radwan P, et al. The effect of environmental exposure to pyrethroids and DNA damage in human sperm. Systems Biology in Reproductive Medicine. 2015;61(1):37-43. 
Lopes TF, Holcman MM, Barbosa GL, Domingos MF, Barreiros RMOV. Laboratory evaluation of the development of Aedes aegypti in two seasons: influence of different places and different densities. Rev. Inst. Med. Trop. 2014;56(5):369-374.

Manjarres-suarez A, Olivero-Verbel J. Chemical control of Aedes aegypti: a historical perspective. Rev. Costarr Salud Pública. 2013; 22(1):68-75

Mitra A, Chatterjee C, Mandal FB. Synthetic Chemical Pesticides and Their Effects on Birds. Research Journal in Environmental Toxicology. 2011;5:81-96.

Moyes CL, Vontas J, Martins AJ, Ng LC, Koou SY, Dusfour I, et al. Contemporary status of insecticide resistance in the major Aedes vectors of arboviruses infecting humans. PLoS Negl Trop Dis. 2017;11(7): e0005625. https://doi.org/10.1371/journal.pntd.0005625

Murphy, AE, Long G. Zika virus: How much do we know about this bug? SciInsigt. 2016;2(9):1-7.

Nganchamung T, Robson MG, Siriwong W. Association between blood cholinesterase activity, organophosphate pesticide residues on hands, and health effects among chili farmers in ubon ratchathani province, northeastern thailand thitirat. Rocz Panstw Zakl Hig. 2017;68(2):175-183.

Palchick S. Chemical Control of Vectors. In: Beaty JB, Marquardt WC. The Biology of the Disease Vectors, Colorado: University Press of Colorado, 1996.p.502-511.

Pialoux G, Gaüzère BA, Jauréguiberry S, Strobel M. Chikungunya, an epidemic arbovirosis. Lancet. Infect. Dis. 2007;7:319-327.

Rivero J, Henríquez-Hernández LA, Luzardo OP, Pestano J, Zumbado M, Boada LD, et al. Differential gene expression pattern in human mammary epithelial cells induced by realistic organochlorine mixtures described in healthy women and in women diagnosed with breast cancer. Toxicology Letters. 2016;246:42-48.

Rose RI. Pesticides and public health: integrated methods of mosquito management. Emerging Infectious Diseases. 2001;7(1):17-23.

Rothwell JT. Residues of zeta-cypermethrin in bovine tissues and milk following pour-on and spray application. Pest Management Science. West Sussex. 2001;57(11):993-999.

Sarah BA, Yeboah PO, Golow A. Levels of Organochlorine Pesticide Residues in Grasscutter (Thryonomys swinderianus) Tissues. Research Journal of Environmental and Earth Sciences. 2011;3(4):350-357.

Soo KM, Khalid B, Ching SM, Chee HY. Meta-analysis of dengue severity during infection by different dengue virus serotypes in primary and secondary infections. Plos one. 2016. http://dx.doi.org/10.1371/journal. pone. 0154760

Teixeira CF, Augusto LGS, Morata TC. Saúde auditiva de trabalhadores expostos a ruído e inseticidas. Rev. Saúde Pública. 2003;37(4):417-423.

Wang A, Cockburn M, Ly TT, Bronstein JM, Ritz B. The association between ambient exposure to organophosphates and Parkinson's disease risk. Occup. Environ. Med. 2014;71:275-281.

Ware GW. An introduction to insecticides. 3. ed. Minnesota: University of Minnesota, 2000.p.496. 